\title{
Juxtaductal left pulmonary artery obstruction in pulmonary atresia
}

\author{
KAZUO MOMMA,* ATSUYOSHI TAKAO,* MASAHIKO ANDO,

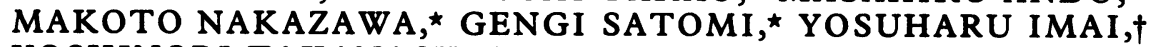 \\ YOSHINORI TAKANASHI, $\dagger$ HIROMI KUROSAWA $†$
}

From the Departments of * Paediatric Cardiology and †Paediatric Cardiac Surgery, Heart Institute of fapan, Tokyo Women's Medical College, Tokyo, fapan

SUMMARY The morphology of the central pulmonary artery was studied by selective angiography in 21 previously unoperated patients (aged 11 days-21 years, median 4 years) with pulmonary atresia associated with various types of congenital heart disease. Angiographic findings were confirmed at operation in 10 patients. There was juxtaductal obstruction of the left pulmonary artery in two thirds of the patients with complete atresia in a quarter. Six of seven patients without juxtaductal obstruction had pulmonary valve atresia, but all nine patients with juxtaductal stenosis had truncal atresia. No patient had stenosis of the right pulmonary artery.

Congenital pulmonary atresia often occurs in association with tetralogy of Fallot, atrioventricular discordance, ventriculoarterial discordance, univentricular heart, or with intact ventricular septum. ${ }^{12}$ Successful correction has been achieved by techniques such as closed or open right ventricular outflow tract reconstruction, ${ }^{34}$ the Rastelli procedure, ${ }^{56}$ or the Fontan procedure. ${ }^{78}$ The presence of normal, or nearly normal, pulmonary arteries is important for successful operation, and peripheral pulmonary stenosis or atresia often make intracardiac repair difficult. ${ }^{910}$ Preoperative diagnosis of peripheral pulmonary stenosis or atresia by conventional diagnostic methods is not easy. Since 1981 we have used preformed catheters to enable us to visualise the ductus arteriosus and adjacent central pulmonary arteries in patients with pulmonary atresia. ${ }^{11}$ We now report the angiographic appearance of the central pulmonary arteries in pulmonary atresia and discuss the development of juxtaductal obstruction of the left pulmonary artery.

\section{Patients and methods}

Since the beginning of November 1981, we have used selective angiography to investigate 77 patients

Requests for reprints to Dr Kazuo Momma, Department of Paediatric Cardiology, Heart Institute of Japan, Tokyo Women's Medical College, Kawada-cho 10, Shinjuku-ku, Tokyo 162, Japan.

Accepted for publication 12 August 1985 with pulmonary atresia associated with various other congenital anomalies in whom the central pulmonary artery originally gave rise to right and left pulmonary arteries. Twenty one patients who had not been treated surgically form the present study group. They range in age from 11 days to 21 years (median 4 years). Eight are males and 13 are females (Table). All were investigated by cross sectional echocardiography and angiocardiography. The morphology of the central pulmonary artery (pulmonary trunk and main branches) was studied by biplane cut-film or cine angiography. After ventriculography or aortography, selective pulmonary angiography was performed by catheterisation of the persistent ductus arteriosus, except in one patient (case 6) in whom the ductus arteriosus was not patent and in five patients under the age of 1 year (cases 1, 2, 7, 8, and 16). In case 6 the entire central pulmonary artery was visualised by pulmonary vein wedge angiography. In the five infants the central pulmonary artery was clearly visualised by aortography. In six patients (cases 16-21) the proximal left pulmonary artery was atretic and angiography through the ductus arteriosus showed only the distal left pulmonary artery. In three (cases 17,18 , and 20) of these six patients a right pulmonary arteriogram was obtained by injection of contrast medium into the right pulmonary vein wedge position.

Two types of pulmonary atresia were identified on angiograms. In pulmonary valve atresia the pulmonary trunk was long and tubular and sinuses 
Table Angiographic data on 21 patients with pulmonary atresia

\begin{tabular}{|c|c|c|c|c|c|c|c|}
\hline Case No & Intracardiac anatomy & Age & Sex & Type of pulmonary atresia & $P D A$ & $\begin{array}{l}\text { Fuxtaductal } \\
\text { proximal }\end{array}$ & $\begin{array}{l}\text { PA obstruction } \\
\text { distal }\end{array}$ \\
\hline $\begin{array}{l}1 \\
2 \\
3 \\
4 \\
5 \\
6 \\
7 \\
8 \\
9 \\
10 \\
11 \\
12 \\
13 \\
14 \\
15 \\
16 \\
17 \\
18 \\
19 \\
20 \\
21\end{array}$ & $\begin{array}{l}\text { VAD, VSD } \\
\text { IVS } \\
\text { UVH } \\
\text { IVS } \\
\text { AVD, VAD, VSD } \\
\text { Fallot } \\
\text { AVSD } \\
\text { VAD, VSD } \\
\text { Fallot } \\
\text { VAD, VSD } \\
\text { UVH } \\
\text { Fallot } \\
\text { Fallot } \\
\text { Fallot } \\
\text { Fallot } \\
\text { Fallot } \\
\text { AVD, VAD, VSD } \\
\text { UVH } \\
\text { Fallot } \\
\text { Fallot } \\
\text { Fallot }\end{array}$ & $\begin{array}{l}11 \mathrm{~d} \\
12 \mathrm{~d} \\
1 \mathrm{yr} \\
3 \mathrm{yr} \\
7 \mathrm{yr} \\
8 \mathrm{yr} \\
4 \mathrm{mnth} \\
8 \mathrm{mnth} \\
1 \mathrm{yr} \\
2 \mathrm{yr} \\
2 \mathrm{yr} \\
2 \mathrm{yr} \\
5 \mathrm{yr} \\
5 \mathrm{yr} \\
21 \mathrm{yr} \\
3 \mathrm{mnth} \\
4 \mathrm{yr} \\
6 \mathrm{yr} \\
9 \mathrm{yr} \\
10 \mathrm{yr} \\
10 \mathrm{yr}\end{array}$ & $\begin{array}{l}\mathbf{M} \\
\mathbf{F} \\
\mathbf{F} \\
\mathbf{F} \\
\mathbf{F} \\
\mathbf{M} \\
\mathbf{M} \\
\mathbf{F} \\
\mathbf{F} \\
\mathbf{M} \\
\mathbf{M} \\
\mathbf{M} \\
\mathbf{F} \\
\mathbf{F} \\
\mathbf{M} \\
\mathbf{F} \\
\mathbf{F} \\
\mathbf{F} \\
\mathbf{M} \\
\mathbf{F} \\
\mathbf{F}\end{array}$ & $\begin{array}{l}V \\
V \\
V \\
V \\
V \\
V \\
T \\
T \\
T \\
T \\
T \\
T \\
T \\
T \\
T \\
T \\
U \\
U \\
U \\
U \\
U\end{array}$ & $\begin{array}{l}+ \\
+ \\
+ \\
+ \\
+ \\
+ \\
+ \\
+ \\
+ \\
+ \\
+ \\
+ \\
+ \\
+ \\
+ \\
+ \\
+ \\
+ \\
+ \\
+ \\
+ \\
+\end{array}$ & $\begin{array}{l}- \\
- \\
- \\
- \\
- \\
\overline{\text { S }} \\
\mathbf{S} \\
\mathbf{S} \\
\mathbf{S} \\
\mathbf{S} \\
\mathbf{S} \\
\mathbf{S} \\
\mathbf{S} \\
\overline{\text { S }} \\
\text { A } \\
\text { A } \\
\text { A } \\
\text { A }\end{array}$ & $\begin{array}{l}- \\
- \\
- \\
- \\
\overline{-} \\
\mathbf{S} \\
\mathbf{S} \\
\mathrm{S} \\
\mathrm{S} \\
\mathbf{S} \\
\mathbf{S} \\
\mathbf{S} \\
\bar{S} \\
\mathbf{S} \\
\mathbf{S} \\
\mathbf{S} \\
\mathbf{S} \\
\mathbf{S}\end{array}$ \\
\hline
\end{tabular}

PDA, persistent ductus arteriosus; VAD, ventriculoarterial discordance; VSD, ventricular septal defect; IVS, intact ventricular septum; UVH, univentricular heart; AVD, atrioventricular discordance; AVSD, atrioventricular septal defect; V, valvar; T, truncal; U, unknown; PA, pulmonary artery; +, present; -, absent; S, stenotic; A, atretic.

of Valsalva were seen at its interior end. In truncal atresia the pulmonary trunk was short and cone shaped. These features were most clearly shown on lateral angiograms. In six patients (cases 16-21) with additional juxtaductal pulmonary atresia, the pulmonary trunk could not be visualised. The ductus arteriosus was left sided in 20 patients, including two with the asplenia syndrome (cases 7 and 10). The remaining patient (case 6 ) had a closed ductus arteriosus.

We use the term juxtaductal obstruction to describe stenosis or atresia of the left pulmonary artery at its junction with the ductus. The diagnosis of postnatal development of juxtaductal atresia was based on the angiographic demonstration, with the catheter in the ductus, of a left pulmonary artery continuous with the ductus, but at an angle to it,

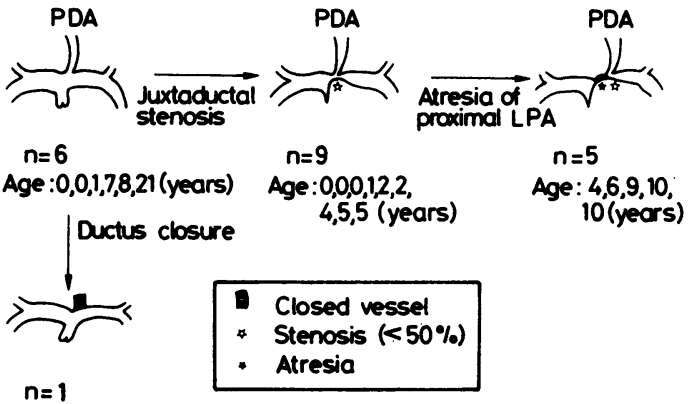

Age 8 ( years)

Fig. 1 Central pulmonary artery patterns in the development of pulmonary atresia associated with congenital heart disease. Numbers of patients and their ages are given. absence of major aortopulmonary collateral artery to the right lung, and demonstration of a right pulmonary artery with normal branching pattern by pulmonary vein wedge angiography. Stenosis of the left pulmonary artery was defined as reduction of the internal diameter to less than $50 \%$ of its largest diameter. Atresia was diagnosed when no contrast medium passed into the central pulmonary artery despite adequate selective injection into the ductus. In 10 of the 21 patients, the central pulmonary artery was explored at operation after angiographic

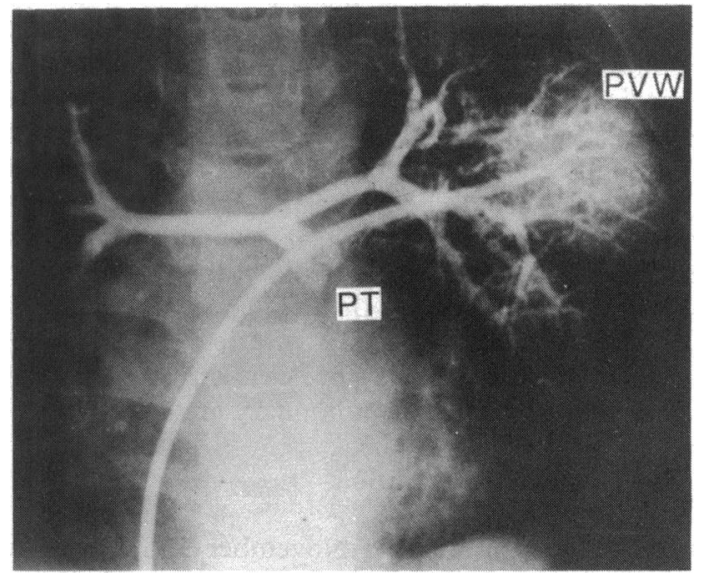

Fig. 2 Central pulmonary artery visualised by pulmonary vein wedge (PVW) angiography in case 6. An end hole catheter was positioned in the left pulmonary vein via a patent foramen ovale. The ductus was closed. A hypoplastic central pulmonary artery and pulmonary trunk (PT) were visualised. Atresia of the pulmonary valve was diagnosed. 


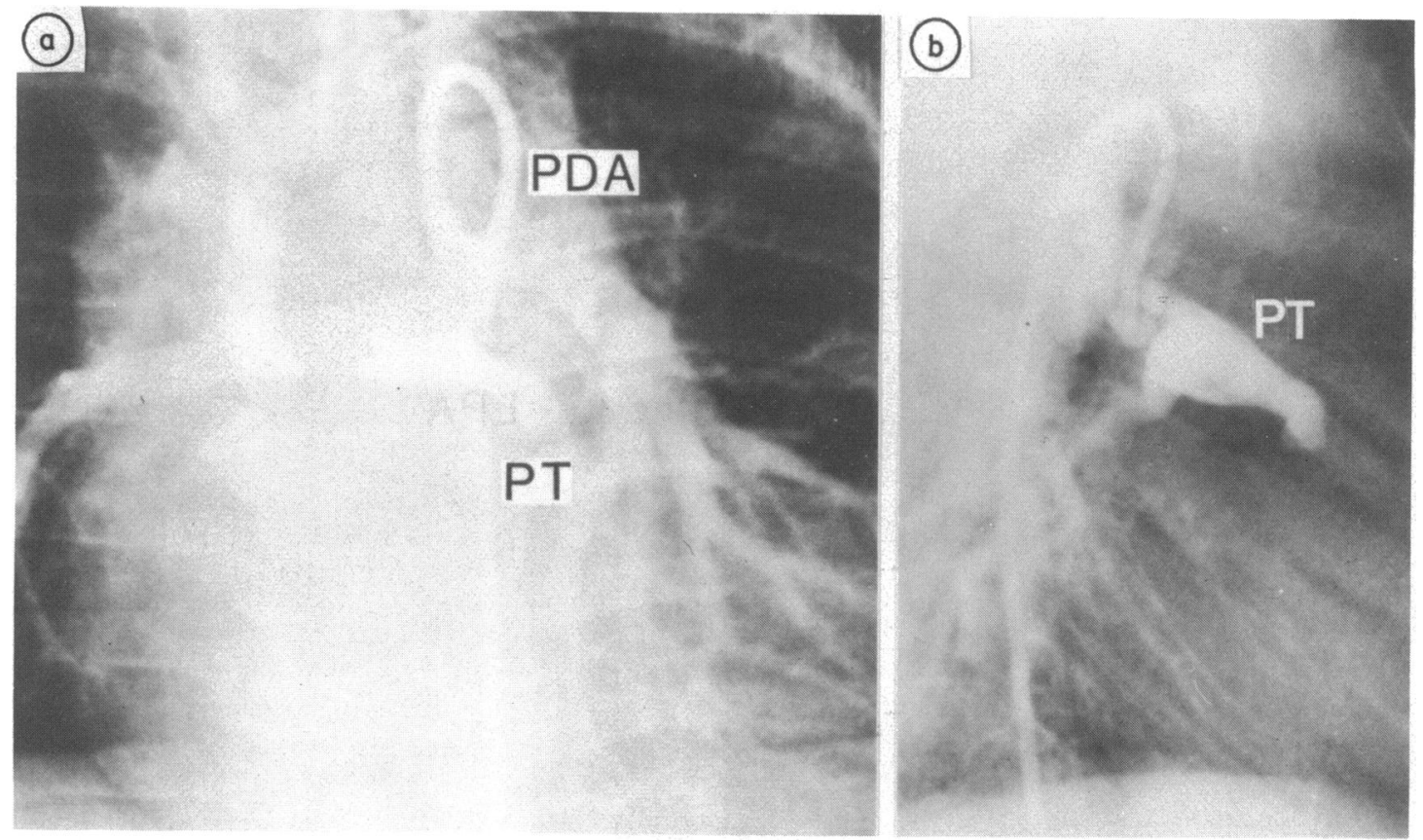

Fig. 3 (a) Selective angiography of the central pulmonary artery through a preformed ductus catheter in a 2 year old girl with tetralogy of Fallot, pulmonary atresia, persistent ductus arteriosus (PDA), and previous left subclavian to pulmonary artery anastomosis. (b) The pulmonary trunk was small with valve atresia. The left pulmonary artery was visualised only faintly because of wash out from the surgically created shunt. Moderate juxtaductal stenosis was present.

study; the angiographic diagnosis was confirmed in all.

\section{Results}

\section{ANGIOGRAMS OF THE PULMONARY ARTERY}

The pulmonary trunk was clearly visualised in 16 patients. There was pulmonary valve atresia in six patients $(43 \%)$ and truncal atresia in the remaining 10 patients.

The appearance of the central pulmonary artery corresponded to one of four patterns (Fig. 1) In seven patients the pulmonary trunk gave rise to right and left branches without stenosis. All these patients except one (case 15) had pulmonary valve atresia. In one (case 6) the ductus was closed, and pulmonary vein wedge angiography showed that the entire central pulmonary artery was hypoplastic (Fig. 2).

In the other 14 patients, there was juxtaductal obstruction of the left pulmonary artery. In nine of these 14 patients the pulmonary trunk divided into right and left pulmonary arteries, but there was a cone shaped narrowing of the left pulmonary artery in each case (Figs. 3, 4, and 5). These nine patients all had truncal atresia. In the remaining five patients, there was complete juxtaductal obstruction, and selective injection of contrast medium into the ductus demonstrated only the left pulmonary artery (Fig. 6). In three of these five patients, pulmonary vein wedge angiography demonstrated normal branching of the right pulmonary artery, though proximal right pulmonary artery and pulmonary trunk were not opacified so that the type of pulmonary atresia could not be determined.

\section{CORRELATION BETWEEN TYPES OF PULMONARY ATRESIA AND JUXTADUCTAL OBSTRUCTION}

Figure 7 shows the age of the patients, the type of pulmonary atresia, and the presence or absence of juxtaductal obstruction. None of the six patients with valvar atresia had juxtaductal obstruction of the left pulmonary artery. In contrast, all except one of those with truncal atresia had juxtaductal obstruction in the left pulmonary artery. Juxtaductal obstruction was more severe proximal than distal to the ductus and five of eight patients aged $>3$ years with juxtaductal obstruction had atresia.

\section{ANGIOGRAMS OF THE DUCTUS ARTERIOSUS}

The ductus arteriosus was visualised clearly in 20 patients and was catheterised in 15 patients. In 18 patients the lung tubular ductus arose from the 

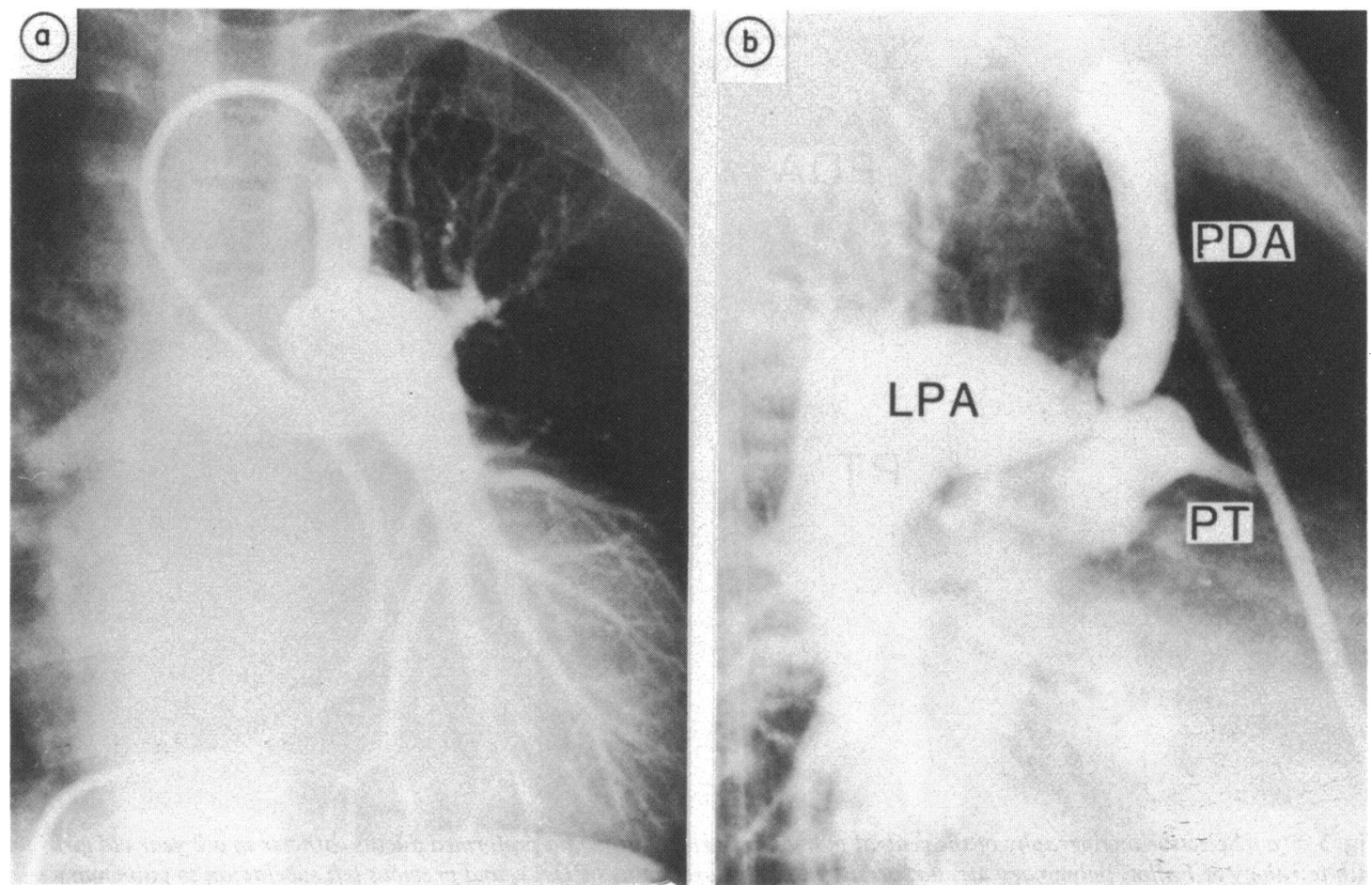

Fig. 4 Selective angiograms of the central pulmonary artery through the ductus in a 13 year old girl with tetralogy of Fallot, pulmonary atresia, persistent ductus arteriosus, and previous Waterston shunt. (a) The balloon catheter was positioned in the persistent ductus arteriosus (PDA) via right atrium, right ventricle, and ascending aorta. (b) fuxtaductal stenosis and atresia of the pulmonary trunk (PT) were clearly demonstrated. LPA, left pulmonary artery. The right pulmonary artery was not well shown because of wash out from Waterston shunt.

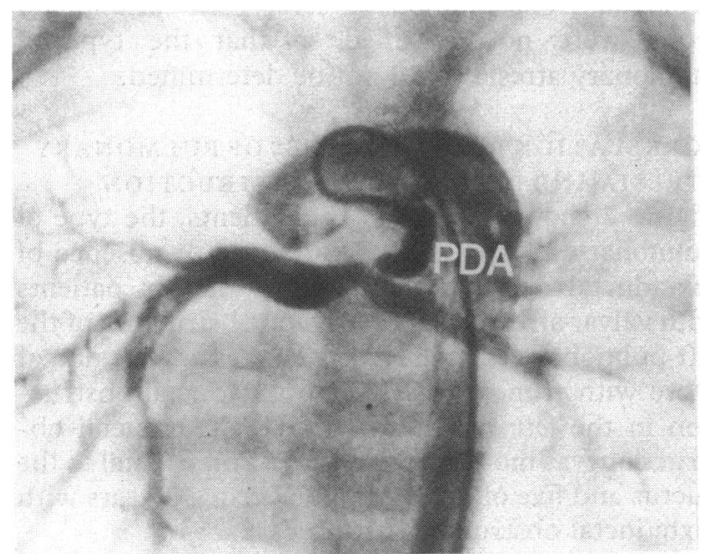

Fig. 5 Selective angiogram of the central pulmonary artery through the persistent ductus arteriosus (PDA) in case 11, showing cone shaped stenotic ductus and juxtaductal stenosis of the left pulmonary artery. Stenosis of the ductus caused contrast material to be regurgitated into the aorta.

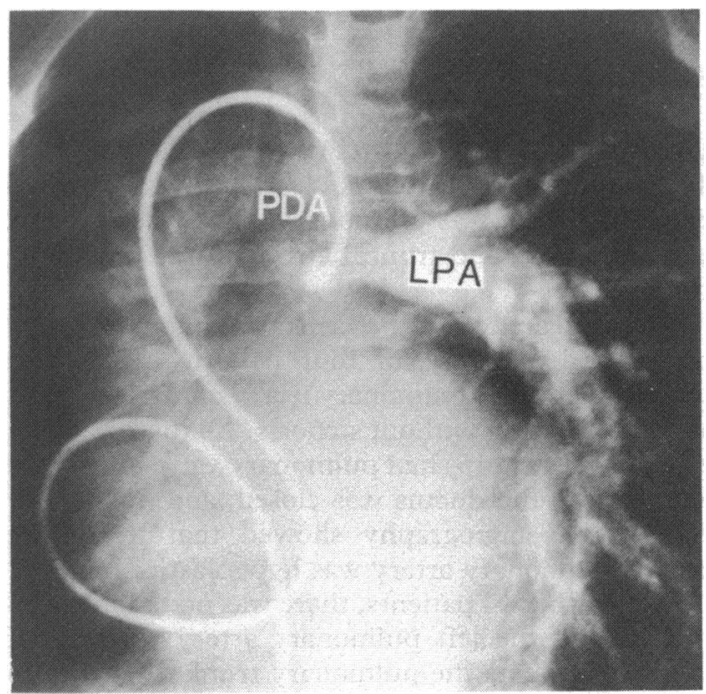

Fig. 6 Selective angiogram of the central pulmonary artery through the ductus in case 19. The cone shaped left pulmonary artery (LPA) was visualised. The pulmonary artery was atretic proximal to the junction with the persistent ductus arteriosus (PDA). The angiographic balloon catheter was inserted into the ductus through the right ventricle and ascending aorta. 


\begin{tabular}{|l|l|l|}
\hline $\begin{array}{l}\text { Juxtaductal } \\
\text { Left pumonary artery }\end{array}$ & None & \\
\cline { 2 - 3 } Obstruction & Stenosis & $\square$ \\
\cline { 2 - 3 } & Atresia & \\
\hline
\end{tabular}

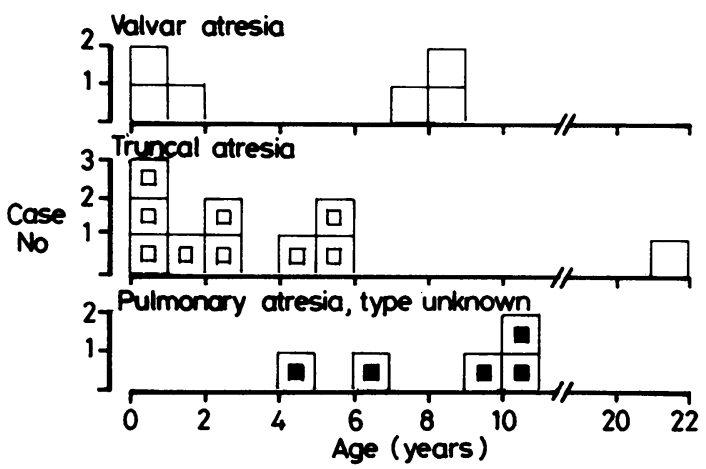

Fig. 7 Types of pulmonary atresia, ages, and juxtaductal obstruction of the left pulmonary artery in patients with pulmonary atresia and no previous operation. Fuxtaductal stenosis developed in infancy and early childhood when the pulmonary trunk was atretic. In contrast, patients with atresia of the pulmonary valve did not develop juxtaductal obstruction.

inferior aspect of the aortic arch with an acute angle between ductus and descending aorta (Fig. 5). In the other two patients, with pulmonary atresia and an intact ventricular septum, the ductus was shorter, originated more caudally at the isthmus, and made an obtuse angle with the descending aorta. The ductus originating from the inferior aspect of the aortic arch was widest at its aortic origin, was tubular or cone shaped, and had localised stenosis at its junction with the pulmonary artery (Figs. 4 and 5). A large ductus could be catheterised with a balloon catheter (Figs. 4 and 6). A small ductus had to be catheterised using a preformed ductus catheter (Figs. 3 and 5).

\section{Discussion}

The development of juxtaductal obstruction of the left pulmonary artery in patients with pulmonary atresia has been described before but not as a definite entity. ${ }^{12-14}$ Our angiographic observations provided not only a diagnosis but also information about the development of juxtaductal obstruction.

Several possible mechanisms have been proposed to explain the development of juxtaductal obstruction. It has been suggested that, as in the case of coarctation of the aorta, ${ }^{15}$ the shearing force of rapid flow leads to development of a jet lesion at the bifurcation of the artery. This mechanism may explain the progression of juxtaductal obstruction after infancy. We, however, have seen juxtaductal obstruction in a 3 month old infant, and the early appearance of this obstruction suggests that ductal constriction may be a factor. Presbitero et al reported evidence to support this hypothesis in one of their patients. ${ }^{12}$ They suggested that as the ductus arteriosus closed, ductal tissue extended into and narrowed the left pulmonary artery.

In the nineteenth century it was suggested that ductal tissue might be a cause of coarctation of the aorta (Skodaic theory). ${ }^{16}{ }^{17}$ More recently this Skodaic theory was invoked to account for angiographically diagnosed juxtaductal stenosis in the left pulmonary artery in tetralogy of Fallot in some patients. ${ }^{1819}$

An understanding of the development of juxtaductal obstruction in pulmonary atresia is relevant to the management of congenital cardiac diseases associated with pulmonary atresia. The present study showed the progressive nature of this lesion, especially proximal to the ductus, and its association with truncal atresia. In patients with truncal atresia, juxtaductal stenosis was already present in infancythe youngest such patient in this series was 3 months old. After the age of 3 years complete juxtaductal atresia increased in frequency, but the small number of observations precluded quantitative statements about its rate of progression. The present study showed that juxtaductal obstruction developed at both sides of the ductal junction with the left pulmonary artery, but that it progressed more rapidly proximal to the junction. The reason for this is not clear. In contrast, we noticed that juxtaductal obstruction progressed more rapidly distal to the junction after left subclavian-pulmonary artery anastomosis (unpublished data). We believe that juxtaductal obstruction may progress more rapidly where blood flow is more turbulent.

It is remarkable that in this study juxtaductal obstruction was an almost invariable finding in patients with truncal atresia but did not occur in those with valvar atresia. This difference is less clear cut in our continuing study of peripheral pulmonary artery stenosis in pulmonary atresia after palliative operation. There are several possible explanations of the association of juxtaductal obstruction with truncal atresia. There is evidence that pulmonary valve atresia, especially when associated with intact ventricular septum, develops later in fetal life than truncal atresia. ${ }^{20}$ This may in turn, lead to differences in development of the juxtaductal portion of the pulmonary artery. Specifically, the size of the pulmonary artery or the distribution of the ductal tissue in the left pulmonary artery may be different in these two types of pulmonary atresia. This remains to be studied.

A few comments are needed on the technique of 
selective angiography of the pulmonary artery in patients with pulmonary atresia and a central pulmonary artery. The origin and shape of the ductus arteriosus in pulmonary atresia are characteristic. ${ }^{1420}$ It arises from the inferior aspect of the aortic arch and makes an acute angle with the descending aorta. We have used three techniques for catheterisation of this type of ductus. In a large high flow ductus, a transvenous balloon catheter (Berman) can be advanced through the right ventricle and ascending aorta into the ductus. An angiographic catheter may also be inserted through the brachial artery. In 1981 we developed a third technique in which we used a preformed ductus catheter. ${ }^{11}$ This catheter is inserted percutaneously from the femoral artery and easily enters the ductus. We have used it extensively in children aged $>1$ year, and even a narrow ductus with an internal diameter of $2 \mathrm{~mm}$ can be entered.

We are indebted to Dr Leonard M Linde, Clinical Professor of Pediatric Cardiology, University of Southern California School of Medicine, and Miss Miyuki Kahn for their help.

\section{References}

1 Thiene G, Anderson RH. Pulmonary atresia with VSD. Anatomy. In: Anderson RH, Macartney FJ, Shinebourne EA, Tynan M, eds. Paediatric cardiology 5. Edinburgh: Churchill Livingstone, 1983: 80-101.

2 Van Praagh R, Ando M, Van Praagh S, et al. Pulmonary atresia. Anatomic considerations. In: Kidd BSL, Rowe RD, eds. The child with congenital heart disease after surgery. Mount Kisco: Futura, 1976: 103-34.

3 Stark J, Huta JC, Macartney FJ. Palliative surgery for pulmonary atresia with ventricular septal defect. In: Anderson RH, Macartney FJ, Shinebourne EA, Tynan M, eds. Paediatric cardiology 5. Edinburgh: Churchill Livingstone, 1983: 126-36.

4 De Laval MR, Bull C. Pulmonary atresia with intact septum. In: Anderson RH, Macartney FJ, Shinebourne EA, Tynan M, eds. Paediatric cardiology 5. Edinburgh: Churchill Livingstone, 1983: 263-73.

5 Pacifico AD. Pulmonary atresia with VSD. Corrective surgery. In: Anderson RH, Macartney FJ, Shinebourne EA, Tynan M, eds. Paediatric cardiology 5. Edinburgh: Churchill Livingstone, 1983: 137-43.
6 Moore CH, Martelli V, Ross DN. Reconstruction of right ventricular outflow tract with a valved conduit in 75 cases of congenital heart disease. $\mathcal{F}$ Thorac Cardiovasc Surg 1976; 71: 11-9.

7 Gale AW, Danielson GK, McGoon DC, Mair DD. Modified Fontan operation for univentricular heart and complicated congenital lesions. $\mathcal{f}$ Thorac Cardiovasc Surg 1979; 78: 831-8.

8 Di Carlo D, Marcelletti C, Nijveld A, Lubbers LJ, Becker AE. The Fontan procedure in the absence of the interatrial septum. $\mathcal{F}$ Thorac Cardiovasc Surg 1983; 85: 923-7.

9 Lincoln C. Discussion on Stark J, Huhta JC, Macartney FJ. Palliative surgery for pulmonary atresia with ventricular septal defect. In: Anderson RH, Macartney FJ, Shinebourne EA, Tynan M, eds. Paediatric cardiology 5. Edinburgh: Churchill Livingstone, 1983:135-6.

10 Olin CL, Ritter DG, McGoon DC, Wallace RB, Danielson GK. Pulmonary atresia: surgical considerations and results in 103 patients undergoing definitive repair. Circulation 1976; 54 (suppl III): 35-40.

11 Momma K, Nakazawa M, Satomi G, Chon Y, Takao A. Pulmonary arteriography through patent ductus arteriosus with preformed catheters. Cathet Cardiovasc Diagn 1983; 9: 319-26.

12 Presbitero P, Bull C, Haworth SG, De Leval MR. Absent or occult pulmonary artery. Br Heart $\mathcal{F} 1984$; 52: 178-85.

13 Keith JD, Rowe RD, Vlad P. Heart disease in infancy and childhood. New York: Macmillan, 1967:584-97.

14 Freedom RM, Culham JAG, Moes CAF. Angiocardiography of congenital heart disease. New York: Macmillan, 1984:195-209.

15 Rosenberg HS. Coarctation of the aorta. Morphology and pathogenetic considerations. Perspect Pediatr Pathol 1973; 1: 339-68.

16 Craigie $D$. Instance of obliteration of the aorta beyond the arch, illustrated by similar cases and observation. Edinburgh Medical and Surgical fournal 1841; 56: 427-62.

17 Skoda J. Protokoll der Sektions-Sitzung fur Physiologie und Pathologie, am 19. Okt. Zeitschrift der kaiserlich-koniglichen Gesellschaft der Aerzte zu Wien 1855: 7: 710-22.

18 Søndergaard $T$. Coarctation of the pulmonary artery. Dan Med Bull 1954; 1: 46-8.

19 Coles JE, Walker WJ. Coarctation of the pulmonary artery. Am Heart $\mathcal{f}$ 1966; 52: 469-73.

20 Kutsche LM, Van Mierop LHS. Pulmonary atresia with and without ventricular septal defect: a different etiology and pathogenesis for the atresia in the 2 types? Am $\mathcal{F}$ Cardiol 1983; 51: 932-5. 